\title{
ESG-befektetés: Az ESG-értékelések alkalmazása smart beta stratégiában*
}

\author{
Stempler Balázs
}

Jóllehet az utóbbi időben nőtt az ESG-befektetések népszerüsége, még mindig bövíthetö lenne a rendelkezésre álló befektetési termékek köre. Egy lehetséges megközelítés az ESG-értékelések és a smart beta stratégia olyan kombinációja, amely egy faktor alapján módosítja az indexsúlyozást, így mind aktív, mind passziv alapkezelésből tartalmaz elemeket. A dolgozatban e módszer alkalmazásával létrehozott hipotetikus alapok 2015 és 2019 között 50 százalék feletti hozamokat értek el, míg a benchmark EURO STOXX 50 mindössze 19 százalékos hasznot hozott a befektetök számára az ötéves időszak alatt. Az ESG-értékelések szignifikánsnak bizonyultak változóként, ami arra utal, hogy képesek befolyásolni a hozamokat, de más tényezők - például a méret vagy a nyereség növekedése - nagyobb magyarázó erővel bírnak. Ezenfelül miközben az ESG-befektetések lehetőségei Magyarországon jelenleg korlátozottak, a piaci szereplők kezdenek ráébredni az ESG potenciáljára, és a javasolt megközelítéssel az alapok új befektetöket vonzhatnának.

Journal of Economic Literature (JEL) kódok: G11, G15, G23, G24

Kulcsszavak: ESG-befektetés, alapkezelés, részvényindexek, smart beta

\section{Bevezetés}

Az ESG ${ }^{1}$-befektetések volumene gyorsan bővül, mivel a befektetők egyre tudatosabbak a megtakarításaik befektetését illetően. E dolgozatban azt vizsgálom, hogy az alapkezelők miként tudják ezt az ügyfeleiktől származó keresletet egy új terméktípussal kielégíteni. A vállalatok környezeti, társadalmi és felelős vállalatirányítási teljesítményének meghatározása érdekében minősítő intézetek ESG-értékeléseket készítenek. Ugyanakkor ezeknek az értékeléseknek a sereghajtó cégek kiszűrésén kívül több felhasználása is lehetséges. E dolgozat célja megmutatni, miként lehetne

\footnotetext{
* A jelen kiadványban megjelenő írások a szerzők nézeteit tartalmazzák, ami nem feltétlenül egyezik a Magyar Nemzeti Bank hivatalos álláspontjával.

Stempler Balázs a Budapesti Müszaki és Gazdaságtudományi Egyetem pénzügy mesterszakos hallgatója. Email: stemplerbalazs@gmail.com

E dolgozat korábbi változata első helyezést ért el az MNB-BME 2020-as kutatási pályázatán zöldpénzügyi kérdések kategóriában. Szeretnék köszönetet mondani Póra Andrásnak és dr. Bethlendi Andrásnak a teljes folyamat során nyújtott iránymutatásért.

Az angol nyelvű kézirat első változata 2020. szeptember 7-én érkezett szerkesztőségünkbe.
}

DOI: http://doi.org/10.25201/HSZ.20.2.91116

${ }^{1}$ környezeti (environmental), társadalmi (social) és felelős vállalatirányítási (governance) tevékenység 
smart beta befektetési stratégia alkalmazásával erősebben összpontosítani az ESG-értékelésekre, egyszerre célozva magasabb hozamokat és ösztönözve a vállalatokat, hogy próbáljanak meg jobban teljesíteni társadalmilag fontos területeken.

A dolgozat bemutat egy évről évre egyre népszerúbbé váló befektetési területet, és segít megérteni, hogy az alapkezelők miként tudnak javítani szolgáltatásaikon és elmozdulni az üzletvitel társadalmilag kívánatosabb módja felé még egy erősen profitorientált ágazatban is. Az ESG-értékelések hozamokra gyakorolt befolyásának megértésére törekszem, valamint bemutatom a módszer alkalmazhatóságát a jelenlegi magyar befektetésialap-piacon.

\section{Az ESG-befektetés fogalma és népszerüsége}

Az ESG-befektetés ESG-tényezők felhasználására utal vállalatok befektetésre való kiválasztásakor, vagyis arra, hogy nagyobb figyelmet kapnak a „társadalmilag felelős” módon múködők. A rövidítés a szervezet által gyakorolt hatás szempontjából figyelembe vett három területet jelzi: környezeti, társadalmi és felelős vállalatirányítási tevékenység. Az ESG-befektetés egy olyan társadalomban született, amely belátta, nem lenne szabad, hogy egyetlen vállalat is kizárólag a profittermelésre összpontosítva múködjön. Napjainkban, amikor az éghajlatváltozás mindennapi életünk problémájává válik, és a dolgozókkal való rossz bánásmódról szóló hírek percek alatt elérhetik a lakosság többségét, a szociális ügyeket a több haszon érdekében figyelmen kívül hagyó vállalatok a jó hírnevüket kockáztatják.

Az ESG-szempontok egyre fontosabbá váltak a társadalomban, és hamar beépültek a befektetési döntésekbe is. Az Ernst \& Young tájékoztató anyaga szerint ${ }^{2} 2012$ óta az ESG-befektetések évente 107 százalékkal nőttek, és 2017-ben az eszközök 18 százaléka ilyen befektetésekhez tartozott. Az ESG-alapokba történő tőkebeáramlás ennél is nagyobb mértékben nőtt az elmúlt néhány évben: lacurci ${ }^{3}$ arról számol be, hogy 2019-ben 20,6 milliárd USD-t fektettek az ESG-re összpontosító befektetési és tőzsdén kereskedett alapokba, ami négyszerese a 2018. évi összegnek. A jelentés arra is kitér, hogy globális szinten az ilyen befektetéseket kínáló alapok száma 300 fölé emelkedett.

Az ESG-befektetés mellett számos olyan kifejezés van, amelyet a fejtegetésekben gyakran egymással felcserélhetően használnak, például fenntartható befektetés, társadalmilag felelős befektetés (SRI), zöldbefektetés és etikus befektetés. Céljuk közös: a befektetési döntések ne csupán a jövedelmezőségen alapuljanak. Ugyanakkor e

\footnotetext{
${ }^{2}$ Sustainable Investing: the millennial investor. Ernst \& Young, 2017. https://www.ey.com/Publication/ vwLUAssets/ey-sustainable-investing-the-millennial-investor-gl/\$FILE/ey-sustainable-investing-themillennial-investor.pdf. Letöltés ideje: 2020. december 28.

${ }^{3}$ lacurci, G.: Money moving into environmental funds shatters previous record. CNBC, 14 Jan 2020. https:// www.cnbc.com/2020/01/14/esg-funds-see-record-inflows-in-2019.html. Letöltés ideje: 2020. december 28.
} 
megközelítések között különbségek vannak. A társadalmilag felelős befektetés a múlt század fő társadalmi problémáiban gyökerezik (pl. polgárjogi mozgalom és a vietnami háborúval való szembenállás az Egyesült Államokban), és kizárólag értékeken alapul, ellentétben a modern ESG-vel, amely nem hagyományos adatokat használ a vállalati teljesítmény értékelésére (Townsend 2020). Az etikus befektetés az SRI-ra hasonlít a jó erkölcsre való fókuszálása miatt, míg a zöldbefektetés csak az ESG környezeti pillérére utal. Végül, a fenntartható befektetés a fenntartható fejlődés céljával van kapcsolatban, azaz jelenlegi szükségletek kielégítése anélkül, hogy veszélyeztetnénk a jövő generációinak képességét, hogy ugyanezt tegye. Kevésbé általános, mégis lényeges befektetési stratégia a vallási meggyőződés alapján történő befektetés. A gondolat az, hogy a befektetők csak olyan vállalatokat válasszanak, amelyek megfelelnek például a keresztény vagy az iszlám értékeknek. A hitalapú befektetés tekinthető a társadalmilag felelős befektetés alegységének, amely az értékeit a vallásra alapozza.

Az ESG-befektetés irányításának általában három különféle módszere van:

1. negatív szürés (negative screening): elkerülni az olyan vállalatokba történő befektetést, amelyek a környezetnek vagy a társadalomnak kárt okoznak;

2. pozitív szúrés (positive screening): a leginkább felelős múködésükről ismert vállalatok kiválasztása;

3. impact investing: egy kívánatos cél megtalálása és olyan vállalatokba történő befektetés, amelyek e cél elérésén dolgoznak.

Nyilvánvaló, hogy a negatív szűrés csak bizonyos területeket szűr ki, míg a pozitív szűrés és az impact investing még kisebb számú lehetőségre korlátozhatja a befektetéseket. Miközben e megközelítések mindegyike inkább összpontosít az ESG-megfontolásokra, mint a szokásos befektetési stratégiákra, az ESG-befektetést a sok választási lehetőség miatt egy skálán kellene szemlélni, és ajánlatos egyértelmúen tisztázni, hogy best-in class alapon történő választásra gondolunk-e vagy negatív szürésre, amikor a témáról beszélünk.

Nem meglepő, hogy a fiatal generációk különösen támogatják az ESG-befektetés gondolatát, mivel az olyan kérdések, mint az éghajlatváltozás és a társadalmi egyenlőség, az ő gondolkodásmódjukhoz közelebb állnak. Állítólag az Y generáció 95 százaléka vonzónak találja az ESG-befektetést, de fontos azt is megjegyezni, hogy nem ők az egyetlenek: az összes válasz 85 százaléka fejez ki valamiféle érdeklődést a koncepció iránt ${ }^{4}$. Ugyanakkor az életkor messze nem az egyetlen tényező, amely befolyásolja az ESG-befektetés vonzerejét, mivel a nem, a jövedelem és az

\footnotetext{
${ }^{4}$ Morgan Stanley Survey Finds Investor Enthusiasm for Sustainable Investing at an All-Time High. 12 Sept 2019 https://www.morganstanley.com/press-releases/morgan-stanley-survey-finds-investor-enthusiasmfor-sustainable-. Letöltés ideje: 2020. december 28.
} 
iskolázottság ugyancsak hatással lehet a befektetők ezen befektetési stratégiát illető magatartására (Cheah et al. 2011).

Az ESG-befektetés erkölcsi haszna vitathatatlan; ha a befektetők nem tudnak nyugovóra térni annak tudatában, hogy pénzüket ártalmas müködés finanszírozására használják, az ESG-befektetés nem csupán egy megfontolandó lehetőség lesz, hanem az egyetlen lehetőség. Ugyanakkor további szempontok áttekintése is szükséges, mivel nem minden befektetés alapul a jó erkölcsön.

Amint már említésre került, az ESG-orientált stratégiák korlátozzák a befektetés szempontjából lehetséges eszközök számát, ami logikusan az e hozamokról való lemaradáshoz vezet. Továbbá a befektetési körből kizárt ágazatok száma jelentős hatással lehet a kockázattal korrigált megtérülésre, ami arra utal, hogy a negatív szúrésnek alternatív költsége van (Trinks - Scholtens 2015). Amint Muller ${ }^{5}$ rámutat, néhány vállalat állíthatja ugyan, hogy környezetileg és társadalmilag felelős, de ezt csak marketingfogásnak használja ahelyett, hogy valóban úgy múködne (pl. a Volkswagen dízelbotránya); ezt gyakran „greenwashing-ként” emlegetik. Ezenkívül nincs kőbe vésve, mit tartanak ESG-szempontból elfogadhatónak. A téma szubjektív és széles körben vitatott, ami az ESG-re vonatkozó bármely döntést még komplexebbé teszi. Pénzügyi szempontból egy további figyelembe veendő tényező, hogy amennyiben a portfólióra szélsőséges korlátozások vonatkoznak, a megfelelő diverzifikáció hiánya miatt megnő a portfólió-elemek koncentrációjának kockázata (Arribas et al. 2019).

Másrészt viszont azt lehet mondani, hogy a vállalatok szűrése nem szükségszerűen csökkenti a megtérülést. Bernow et al. (2017:3) például rámutat, hogy a hírnévrontás jelentős kockázati tényező lehet a vállalatok számára. Az olyan vállalatok kiszűrésével, amelyek ellen valószínúleg pereket indítanak, vagy tevékenységük miatt büntetéseket kell fizetniük, vagy ha márkanevük rossz viselkedéshez kötődik, a befektetők ténylegesen növelhetik hozamukat azáltal, hogy portfóliójuk nem tartalmaz ilyen állományokat.

Az Etergino Group 2018-as jelentése szerint ${ }^{6} 2009$ és 2017 között az MSCl ACWI ESG-index a sok fejlett és feltörekvő részvénypiac teljesítményét megragadó eredeti $\mathrm{MSCl}$ ACWI-indexszel csaknem azonos (évente 0,1 százalékponttal magasabb) hozamokat produkált. Az MSCI ACWI ESG-indexbe 1904 részvényt válogattak, míg a nem ESG-indexnek 2450 komponense volt 2017-ben. Az ESG-index kiejti a leggyengébb ESG-profilú vállalatokat, és megváltoztatja az eredeti súlyozást is. Az eredmények hasonlósága azt jelezheti, hogy a figyelembe vehető befektetési lehetőségek

\footnotetext{
${ }^{5}$ Muller, C.: The Pros and Cons of Socially Responsible Investing. DoughRoller, 7 Dec 2020 https://www. doughroller.net/investing/pros-and-cons-of-socially-responsible-investing/. Letöltés ideje: 2020. december 28.

${ }^{6}$ The Benefits of ESG Investing: How Socially Responsible Investing Can Drive Outperformance. Etergino Group 2017 https://us.rbcwealthmanagement.com/documents/170410/170426/18-WG-774_Etergino+Group Benefits+of+ESG+Investing+Flyer_evite.pdf/2f645a56-155e-4b55-8bc2-3e1a61fc84b6. Letöltés ideje: 2020. december 28 .
} 
csökkenését ellensúlyozza a múködési és reputációs kockázatoknak a jobb ESG-profilokkal együtt járó csökkenése.

\section{1. táblázat \\ Egyes indexek és ESG-változataik hozamai}

\begin{tabular}{l|c|c|c|c|c}
\multicolumn{1}{r|}{ Index megnevezése } & $\mathbf{2 0 1 6}$ & $\mathbf{2 0 1 7}$ & $\mathbf{2 0 1 8}$ & $\mathbf{2 0 1 9}$ & $\begin{array}{c}\text { Kumulatív } \\
\text { hozam }\end{array}$ \\
\hline S\&P 500 & $9,5 \%$ & $19,4 \%$ & $-6,2 \%$ & $28,9 \%$ & $58,08 \%$ \\
\hline S\&P 500 ESG Index & $9,9 \%$ & $18,7 \%$ & $-5,9 \%$ & $30,6 \%$ & $60,32 \%$ \\
\hline FTSE 100 & $16,8 \%$ & $13,1 \%$ & $-9,5 \%$ & $19,2 \%$ & $48,80 \%$ \\
\hline FTSE 100 ESG Select & $20,4 \%$ & $10,7 \%$ & $-8,9 \%$ & $17,7 \%$ & $42,91 \%$ \\
\hline MSCI ACWI & $7,9 \%$ & $24,0 \%$ & $-9,4 \%$ & $26,6 \%$ & $53,46 \%$ \\
\hline MSCI ACWI ESG Index & $7,2 \%$ & $24,1 \%$ & $-9,3 \%$ & $28,0 \%$ & $54,45 \%$ \\
\hline
\end{tabular}

Hogy reprezentatívabb képet kapjunk, összegyűjtöttem három indexnek a jelen dolgozat írásakor legfrissebb éves hozamait, és összehasonlítottam őket ESG-változataikkal (1. táblázat). A különbség a fent említett 0,1 százaléknál nagyobb, de összességében a hozamok éves alapon mégis hasonlóak. Az adatok alapján kirajzolódó trend az, hogy amennyiben az ESG-index egy adott évben felülmúlta az eredeti indexet, vagy az alatt maradt, a következő évben az ellenkezője történik. Miközben az S\&P 500 ESG változata túlteljesítette a benchmarkját, az FTSE 100 hozamaihoz nem illeszkedett a módosított változata. A fent említett MSCI ACWI és ESG megfelelője közötti különbség volt a legkisebb a három pár közül.

Az előbb idézett statisztikák szokásos piaci viszonyokat tükröznek. Ugyanakkor a Covid-19-járvány és a részvénypiacokra gyakorolt kezdeti negatív hatása lehetőséget nyújt számunkra feszült gazdasági körülmények vizsgálatára, hogy lássuk, miként teljesít az ESG a gazdasági kilátások rosszabbodásakor. A világjárvány következtében 2020 márciusában a részvénypiacok a valaha volt legrosszabb napjaikat szenvedték el. Piaci feszültség idején a befektetések középpontjába az olyan biztonságos eszközök kerülnek, mint az arany vagy az USD, miközben a részvénypiacon maradó befektetők olyan biztonságos részvények felé fordítják figyelmüket (és tőkéjüket), amelyek egy visszaesés idején jobban teljesítenek a ciklikus értékpapíroknál. Amennyiben az ESG alkalmazása ténylegesen csökkenteni tudja a kockázatokat, az ESG-tudatos vállalatok teljesítményének e feltételek mellett felül kellett volna múlnia az általános piacot. Hale összehasonlította 206 alap első negyedévi hozamát, és azt találta, hogy az ESG-fókuszúak jobban teljesítettek. Az ESG-alapok 70 százaléka a piacain az átlagosnál jobb hozamokat ért el, és teljesítmény alapján az ilyen alapoknak mindössze 11 százaléka tartozott a legrosszabb kvartilishez. Megvizsgálta a földrajzi eloszlást is: 12 egyesült államokbeli alapból 10-nek sikerült - átlagosan több mint 1 százalékponttal - felülmúlnia benchmarkját, miközben más fejlett piacokon minden egyes ESG-alap közel 2 százalékpontnyi többlethozammal teljesítette túl 
benchmarkját. Úgy találta, a jelenséghez hozzájárul az is, hogy az ESG-alapok nem, vagy legalábbis kis súllyal tartalmaznak néhány olyan energiaszektorbeli részvényt, amely különösen gyengén teljesített márciusban. Megjegyzi ugyanakkor, hogy a befektetési teljesítmény tényezőinek elemzése alapján ez a megfigyelés csak másodlagos jelentőségű. Szerinte az elsődleges ok az, hogy a magasabb ESG-értékelésű vállalatok jobban bánnak az érdekeltjeikkel, és felelősebb módon múködnek, ami tökéletes jelöltekké teszi őket, hogy túléljék a váratlan sokkokat

\section{ESG-értékelések}

\subsection{Az ESG-értékelések előnyei}

Ha a befektetők ESG-megfontolások alapján kívánják tőkéjüket befektetni, időigényes akadállyal szembesülnek, mivel fáradságos feladat lehet meghatározni, hogy egy vállalat valójában mennyire ESG-barát. Egy kezdeti negatív szűrés tűnik a legegyszerűbb résznek; néhány ágazat (pl. dohány) objektíve kizárható az ESG-befektetésből, ugyanakkor az ágazati szintű osztályozást követően a vállalatspecifikus döntés már nehezebbnek bizonyul.

Egy szervezet építheti úgy a márkáját, hogy az ESG-re fókuszálónak tűnjön, ami akaratlan részrehajlást alakít ki az egyénben, aki a befektetési döntést hozza. Ez az elfogultság csak részletes kutatással győzhető le, ami több okból is nehéz:

1. A vállalatok arra vannak motiválva, hogy jelentéseikben az önmagukra vonatkozó pozitív véleményeket emeljék ki, miközben elrejtik a környezeti vagy társadalmi teljesítményükre vonatkozó, potenciálisan hátrányos információkat. Ilyen gyakorlatot tárt fel az energiaszektorban Talbot-Boiral (2018).

2. A rendszabályok jelentősen eltérnek az egyes régiók és országok között. Az Európai Unió (a nem pénzügyi információk közzétételéről szóló irányelvben) megköveteli a nagyvállalatoktól, hogy olyan nemzetközi vagy nemzeti szabványokon alapuló fenntarthatósági jelentéseket adjanak ki, mint az ISO 26000 vagy az OECD irányelvei, miközben az Egyesült Államokban a vállalati fenntarthatósági jelentések nem kötelezőek. E jelentések az ESG-információk egyik forrásául szolgálhatnának, de a fenntarthatósági jelentés gyakran még mindig csak néhány, alig részletezett adatot tartalmaz, amelyek nem elégségesek a befektetők számára a megalapozott döntéshozatalhoz ${ }^{8}$.

\footnotetext{
${ }^{7}$ Hale, J.: Sustainable Funds Weather the First Quarter Better Than Conventional Funds. Morningstar. 3 Apr 2020. https://www.morningstar.com/articles/976361/sustainable-funds-weather-the-first-quarter-betterthan-conventional-funds. Letöltés ideje: 2020. december 28.

${ }^{8}$ What investors want to know about ESG metrics. EY Reporting, 5 March 2018. https://www.ey.com/en_gl/ assurance/what-investors-want-to-know-about-esg-metrics. Letöltés ideje: 2020. december 28.
} 
3. A vállalatok általában a saját iparágukban fontosnak tartott mutatókat használnak, ami még bonyolultabbá teszi a helyzetet a befektetők számára, akik számos ágazatról nem rendelkeznek elegendő információval.

E nehézségek feltárása az adott üzletágakra szakosodó elemzők által készített ESG-értékelések előnyeként is értékelhető. Az ESG-értékelésekkel minden összetett és időigényes feladat a szakértőkre marad, akik olyan végleges adattá alakítják ezeket, amely összefoglalja a vállalat ESG-teljesítményét. A végfelhasználónak (legyen az kisbefektető vagy alapkezelő) csak arról szükséges megbizonyosodnia, hogy a minősítő intézet által alkalmazott módszer összhangban van az elvárásaival, aztán kényelmesen támaszkodhat az eredményre.

\subsection{ESG-minősítő intézetek és az MSCI minősítési módszer}

Az ESG-minősítő szervezetek felbukkanása megelőzte az ESG-befektetés volumenének utóbbi néhány évben látott jelentős megugrását. 2010-ben már tíz intézet nyújtotta e szolgáltatást. Akkoriban ezek az intézetek értékelési módszereiket tekintve jelentősen különböztek egymástól, és egyhangúlag egyik iparágat se zárták ki, de egyes területeket gyakran jelöltek „vitatottként” (Escrig-Olmedo et al. 2010). Ezenkívül az intézetek különböző szabványokat vettek figyelembe, néhányan pl. az ISO-szabványokra, a Kiotói Jegyzőkönyvre, illetve az ENSZ Emberi Jogok Egyetemes Nyilatkozatára alapozták döntésüket.

Az ESG-minősítő ágazat azonban a kezdetekhez képest megváltozott. Douglas et al. (2017) rámutatott, hogy az ügyfelek részére történő átfogóbb szolgáltatásnyújtás érdekében végrehajtott számos felvásárlásnak köszönhetően az ágazat konszolidáción ment át. A 2010-ben vizsgált tíz szakosodott intézmény némelyike még mindig müködik, de megjelentek nagyobb, másféle adatbázisokat is nyújtó piaci szereplők, jelezve, hogy a korábban ritkán figyelembe vett ESG-tényezők a mainstream befektetési döntések részévé váltak.

Ilyen adatbázis-szolgáltatók a Bloomberg, az FTSE Russell, az MSCl és a Thomson Reuters. ESG-értékeléseket, egyedi tényezők felbontását és számos indexet kínálnak (Douglas et al. 2017:5). Számításaik részleteinek eléréséért díjat kell fizetni, de az $\mathrm{MSCl}$ - versenytársaival ellentétben - a végleges értékelést ingyenesen nyújtja. Ezáltal a lakossági befektetők számára is vonzóvá teszi szolgáltatását, miközben az alapkezelőknek és hivatásos befektetőknek egyébként is van hozzáférése ezekhez az adatbázisokhoz. 
Egy újabb keletú publikáció szerint a tíz évvel ezelőtti állapothoz képest az intézetek az új kihívások jobb tükrözése érdekében új kritériumok beépítésével fejlesztették modelljeiket, de az eljárás még mindig nem tökéletes, és a végleges eredmények elfogadása előtt mindig ajánlatos megismerkedni a módszer részleteivel (EscrigOlmedo et al. 2019).

Honlapján az $\mathrm{MSCl}$ áttekintést nyújt a módszeréről, amelyet itt foglalok össze ahhoz, hogy megértsük, hogyan születnek meg a végleges ESG-értékelések ${ }^{9}$. A szemléltetés másik célja e módszer bemutatása az általam később tárgyalt befektetési stratégiával való összefüggése miatt.

Az MSCl kvantitatív és kvalitatív adatok alapján egyaránt értékeli az ESG-teljesítményt. 37 olyan kulcsfontosságú tényezőt azonosítottak, amely ESG-kockázatoknak tehet ki egy szervezetet, lehetőséget biztosítva ugyanakkor arra is, hogy e kockázatokat helyesen kezeljék. A kulcskérdések a környezeti, a társadalmi és a vállalatirányítási pillérhez tartoznak. A pillérek tíz témát ölelnek fel: az éghajlatváltozás, természeti erőforrások, környezetszennyezés, hulladék és környezetvédelmi lehetőségek a környezeti pillér keretébe tartozik; az emberi erőforrás, termékfelelősség, érdekeltek szembenállása és társadalmi lehetőségek a társadalmi pillérben, vállalatirányítás és vállalati magatartás az irányítási pillérbe tagozódik. A kulcsfontosságú kérdéseket évente áttekintik, és szükség esetén aktualizálják, iparági szinten pedig, két tényező alapján, különböző súlyt kapnak. E két tényező a környezeti és társadalmi hatáshoz való hozzájárulás szintje, valamint a kockázat/lehetőség megvalósulásának várható időkerete. $\mathrm{Az} \mathrm{MSCl}$ példája szerint egy nagy hatású és rövid távú problémának háromszor nagyobb a súlya, mint egy kis hatású és hosszú távú problémának.

Minden egyes kulcskérdés esetén - annak meghatározásához, hogy egy vállalat miként boldogul egy ágazatban - egyaránt figyelembe veszik a kockázati kitettség szintjét és a kockázatkezelés minőségét. Az e mögött meghúzódó gondolat az, hogy amennyiben egy vállalat nagyon ki van téve valamilyen kockázatnak (például elavult, szennyező technológiákat alkalmaz), az jelentősebb kockázatcsökkentést követel meg a vezetésétől, míg egy alacsonyabb kockázati kitettségű cég részéről mérsékelt kockázatkezelés is elégséges lehet. Ugyancsak figyelmet kapnak az ellentmondások: a hatás mértéke és jellege alapján minden eseményt kategorizálnak, és hozzárendelnek egy súlyt, amelyet belefoglalnak a végleges számításba. $\mathrm{Az} \mathrm{MSCl}$ további adatok felajánlására is lehetőséget ad a szervezeteknek, hogy a cég tevékenységéről átfogóbb képet lehessen kapni.

\footnotetext{
${ }^{9} \mathrm{MSCI}$ ESG Research: ESG Ratings. Measuring a company's resilience to long-term, financially relevant ESG risks. 2019. https://www.msci.com/documents/1296102/14524248/MSCl+ESG+Ratings+Methodology+-+Exec+Summary+2019.pdf/2dfcaeee-2c70-d10b-69c8-3058b14109e3?t=1571404887226. Letöltés ideje: 2020. december 28.
} 
A végeredmény egy AAA és CCC közötti értékelés. A hitelminősítésekhez hasonlóan az AAA-t tekintik a legjobbnak. A hét minősítés mindegyike a 0-10 közötti skála egy hetedét fedi le, amely az elvégzett számítások végeredménye. Jelenleg évente részvények ezreit értékelik, vizsgálják felül és aktualizálják. A végleges ESG-értékelés, a múltbeli értékelések, az értékelés megoszlása az ágazatban, valamint a példák azon területekre, ahol egy vállalat jól és gyengén teljesít, ingyenesen rendelkezésre állnak, de a súlyokhoz és a részletes pontszámokhoz felár ellenében lehet hozzáférni.

\section{Smart beta befektetés}

\subsection{Aktív és passzív alapkezelés, valamint a smart beta fogalma}

Hagyományosan két portfóliókezelési kategóriát különböztetünk meg: aktív és paszszív. Az aktívan kezelt alapok célja általában a benchmarkjuk túlteljesítése, vagy pedig van egy meghatározott befektetési céljuk. Az aktív befektetés a részvények kiválasztásának és a piac időzítésének képességeire épít, amelyek kihívást jelentő feladatok, és így az ilyen alapkezelők viszonylag magas kezelési díjat számítanak fel a szakértelmükért. Másrészt a passzív alapkezelés célja egy piaci index hozamainak lehető legszorosabb replikálása; ezért a befektetés felosztása egy index összetételén alapul, miközben az aktív befektetők egyedibb stratégiákat alkalmazhatnak. Passzív befektetés esetén nincs szükség az ágazatok és árak kiterjedt kutatására, így az ilyen alapok díjai sokkal alacsonyabbak az aktívan kezelt alapokénál.

Az aktívan kezelt alapokba történő befektetés mellett szóló érv a lehetőség a piac teljesítményének felülmúlására. Ugyanakkor az utóbbi tíz évben az aktív alapok mindössze 23 százalékának sikerült megverniük passzív megfelelőjüket. Riquier a piaci szegmensek közötti nagy különbségekre is rámutat: az egyesült államokbeli nagy vegyes alapoknak (amelyek egyaránt fektetnek egyesült államokbeli magas kapitalizációjú részvényekbe és növekvő vállalatokba) csak 8 százaléka volt képes felülmúlni benchmarkját, miközben a nem amerikai kis és közepes kapitalizációjú cégekbe fektető alapok 82 százaléka tette ezt meg ${ }^{10}$. Kutatók alaposan vizsgálták az alapkezelők részvénykiválasztási és piaci időzítési készségeit, ami az adatok gyakoriságától és az alkalmazott időhorizonttól függően különféle eredményekhez vezetett (Rompotis 2009).

\footnotetext{
${ }^{10}$ Riquier, A.: More evidence that passive fund management beats active. Marketwatch. 12 Sept 2019. https:// www.marketwatch.com/story/more-evidence-that-passive-fund-management-beats-active-2019-09-12. Letöltés ideje: 2020. december 28.
} 


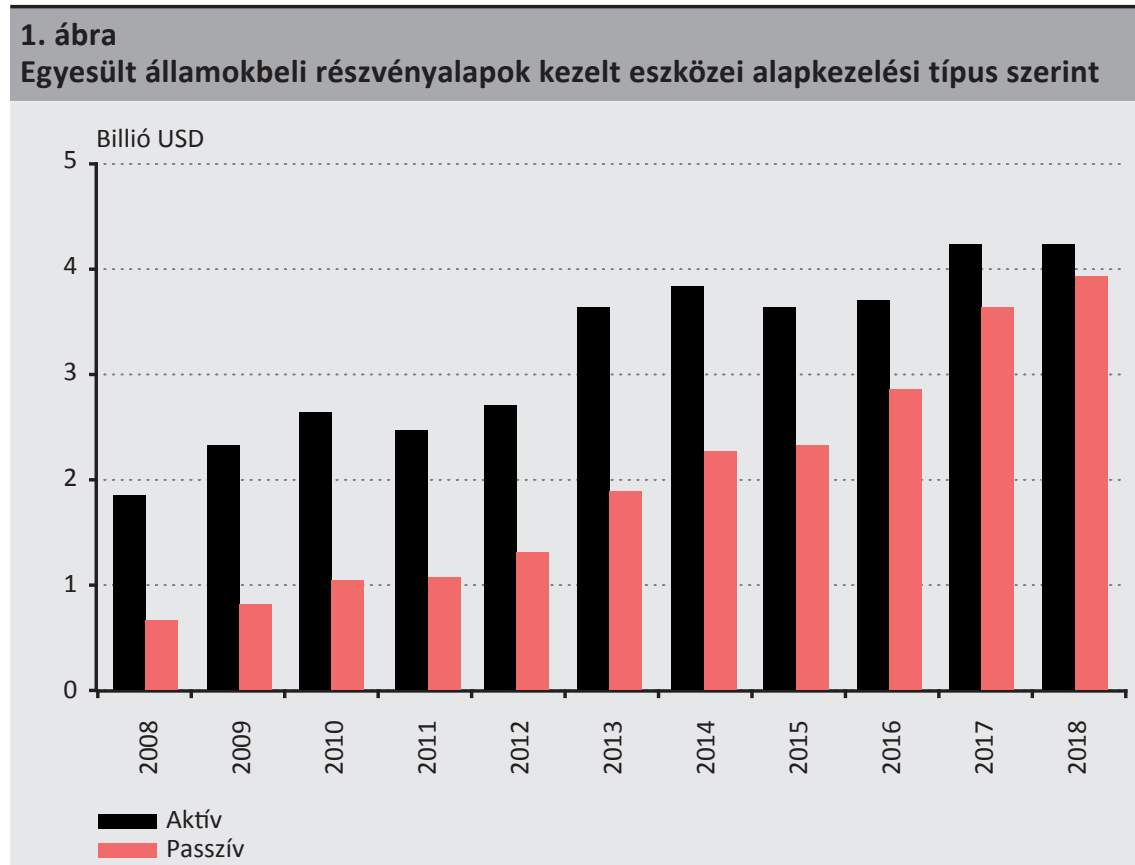

Forrás: Stein, C.: Shift From Active to Passive Approaches Tipping Point in 2019. Bloomberg article, 31 December 2018. https://www.bloomberg.com/news/articles/2018-12-31/shift-from-active-to-passiveapproaches-tipping-point-in-2019. Letöltés ideje: 2020. december 28.

Az utóbbi évtizedekben népszerúbbé vált a passzív befektetés: előbb a hatékony piacok elmélete szolgált elméleti alappal e megközelítés számára, majd az indexalapok megjelenése és a csökkenő költségek késztették a befektetőket arra, hogy újragondolják az aktívan kezelt portfóliókra vonatkozó szükségletüket. A passzív befektetés (1. ábra) növekvő népszerűségét kíséri az ETF-ek (tőzsdén kereskedett alapok) növekedése. Az ETF-eket a befektetők főként passzív befektetési eszközként használnak egy index hozamainak replikálására. Az utóbbi évtizedben is folyamatosan növekedtek, és jelenleg a kereskedési tevékenység egyharmad részét teszik ki az USA-ban. Az utóbbi tíz évben 3,5 billió USD-t fektettek ETF-ekbe, ami mutatja, mennyire jelentőssé váltak ${ }^{11}$. Megjegyzendő ugyanakkor, hogy a passzív befektetés közelmúltbeli sikere egy hosszú bikapiacon következett be, és a legtöbb piaci korrekció esetén az aktív alapkezelők jellemzően jobban teljesítenek ${ }^{12}$. Az aktívtól a passzív befektetés felé való elmozdulásnak vannak a pénzügyi rendszerre irányuló hatásai is, ideértve a megnövekedett ágazati koncentrációt, az index-beleszámítás

${ }^{11}$ Flood, C.: Popularity of passive investing changes rules of the game. Financial Times, 22 Oct 2019. https:// www.ft.com/content/3cc857e0-d0c0-11e9-b018-ca4456540ea6. Letöltés ideje: 2020. december 28.

${ }^{12}$ Friedmann, C.: To Be Active Or Passive During The Coronavirus Crisis. The Wealth Advisor, 6 May 2020. https://www.thewealthadvisor.com/article/be-active-or-passive-during-coronavirus-crisis. Letöltés ideje: 2020. december 28. 
(index-inclusion) hatását, valamint a tőkeáttétellel múködő és inverz ETF-ek miatt felerősödött volatilitást (Anadu et al. 2020).

A smart beta befektetés egy harmadik opciót kínál az aktív és passzív alapkezelés mellett. Elnevezése a bétára utal, amely a volatilitás mértéke a pénzügyekben. Az indexkövető alapok bétája elméletben egynek felel meg, és ezek az alapok csak rendszerszintű kockázatot hordoznak, mivel összetételük megegyezik a piaci benchmarkéval, míg az aktív alapok bétája a portfólió felépítésén alapul, és az aktív befektetés idioszinkratikus kockázattal is jár. A smart beta stratégia elnevezése technikailag nem kapcsolódik e pénzügyi mutatóhoz, inkább csak marketingeszközként használják egy befektetésitermék-típushoz.

A stratégia abból a tényből ered, hogy a legtöbb piaci index piaci kapitalizációval súlyozott. Mivel a piaci kapitalizáció a forgalomban levő részvények számának és a jelenlegi részvényárfolyamnak a szorzata, minél nagyobbak ezek a számok, annál nagyobb a súlyuk az indexben. Ez a megközelítés nem biztos, hogy kézenfekvő azon befektetők számára, akik nem momentumalapú befektetési stratégiát követnek, azaz nem kívánnak megtakarításukból többet elhelyezni egy értékpapírba, amikor annak ára (minden egyéb körülmény változatlansága mellett) emelkedik.

A piaci kapitalizáció alapú indexsúlyozási rendszerrel egy index értéke néhány nagyon magas piaci kapitalizációjú vállalat értékpapírjaiban koncentrálódik. 2020 elején az Apple, a Microsoft, az Alphabet, az Amazon és a Facebook az S\&P 500 17,5 százalékát tette ki, aláásva az index célját, amely egy jól diverzifikált egyesült államokbeli piacnak való kitettség biztosítása ${ }^{13}$. A márciusi tőzsdekrachot követő gyors emelkedés során ez az arány tovább növekedett, és augusztus végére 24 százalékot ért el.

A smart beta módosítja az indexkomponensek súlyait, alul- vagy túlsúlyozva azokat a benchmark-indexben levő kitettségükhöz képest. A módosított súlyok egy olyan faktoron alapulnak, amelyről az alapkezelő úgy véli, hogy szoros kapcsolatban van a magasabb hozamokkal. Egy ilyen tényező kiválasztásának sok lehetősége van (pl. méret, volatilitás vagy osztalékhozam), és néha egynél több tényezőt is alkalmaznak.

\footnotetext{
${ }^{13}$ Levy, A. - Konish, L.: The five biggest tech companies now make up 17.5\% of the S\&P $500-$ here's how to protect yourself. CNBC, 1 January 2020. https://www.cnbc.com/2020/01/28/sp-500-dominated-by-applemicrosoft-alphabet-amazon-facebook.html. Letöltés ideje: 2020. december 28.
} 


\begin{tabular}{l|l|l|l}
\hline \multicolumn{2}{l}{$\begin{array}{l}\text { 2. táblázat } \\
\text { Az aktív és passziv alapkezelés jellemzőinek összehasonlítása és a smart beta }\end{array}$} & \multicolumn{1}{|c}{ Aktív alapkezelés } & \multicolumn{2}{c}{ Passzív alapkezelés } & \multicolumn{1}{c}{ Smart beta befektetés } \\
\hline Befektetés alapja & Alapkezelő mérlegelése & Egy indexet követ & $\begin{array}{l}\text { A kiválasztott faktoron } \\
\text { alapul }\end{array}$ \\
\hline Alapkezelési díjak & Viszonylag magas & $\begin{array}{l}\text { Sokkal kevesebb, mint az } \\
\text { aktív alapoknál }\end{array}$ & $\begin{array}{l}\text { Alacsonyabb, mint az aktív } \\
\text { alapoknál }\end{array}$ \\
\hline Átsúlyozás & Alapkezelő mérlegelése & $\begin{array}{l}\text { Csak akkor, ha az index } \\
\text { összetétele változik }\end{array}$ & $\begin{array}{l}\text { Amikor a faktorértékek } \\
\text { változnak }\end{array}$ \\
\hline Kockázati profil & Idioszinkratikus kockázat & Rendszerszintű kockázat & $\begin{array}{l}\text { Módosított rendszerszintű } \\
\text { kockázat }\end{array}$ \\
\hline Átláthatóság & $\begin{array}{l}\text { A befektetési döntéseket } \\
\text { nem szükségszerúen } \\
\text { kommunikálják }\end{array}$ & Erősen átlátható & $\begin{array}{l}\text { A befektetés előzetesen } \\
\text { meghatározott szabályon } \\
\text { alapul }\end{array}$ \\
\hline
\end{tabular}

A smart beta passzív és aktív alapok elemeit is kombinálja, jellemzőit a 2. táblázat foglalja össze. Tekinthetjük passzívnak, mert egy olyan szabályt követ, amely pontosan meghatározza, hogyan történik a pénz allokációja. Ugyanakkor - mivel eltér az index eredeti összetételétől - aktív befektetésnek is tekinthető. Kockázati profilja közelebb áll a passzív befektetéséhez, mivel valamilyen benchmark-index alkotóelemeit használja, de módosítva a súlyokat, így bizonyos mértékben eltér a tiszta rendszerszintű kockázattól.

A smart beta portfóliók igényelnek némi kezelést, mert a faktort meg kell határozni, és a súlyokat ki kell számítani, továbbá át kell súlyozni, amikor a faktor értékei változnak (általában éves vagy negyedéves alapon, a kiválasztott faktortól függően). Így a kezelési díjaknak meg kell haladniuk a passzív alapokét, de alacsonyabbnak kell lenniük, mint az aktív alapok díjai. Úgy tűnik, ez az elmélet megfelel a gyakorlatnak is; Rabener ${ }^{14}$ megállapította, hogy a smart beta alapok átlagos költségaránya mintegy 0,3 százalék, ami az USA 0,13 százalékos passzív alapok eszközzel súlyozott átlagos költségaránya és az aktív alapok 0,66 százaléka között van ${ }^{15}$.

Az aktív alapok kezelőivel ellentétben a smart beta kezelők nem hoznak saját megítélésükön alapuló döntéseket, mivel mindig a kiválasztott faktort kell követniük, átláthatóbbá téve ezeket az alapokat az aktív alapokhoz képest, ahol a befektetők nem mindig tudják előre vagy értenek egyet a portfóliókezelő döntéseivel.

\footnotetext{
${ }^{14}$ Rabener, N.: Factor Scoring Smart Beta ETFs. Factorresearch.com, January 2020. https://www.factorresearch. com/research-factor-scoring-smart-beta-etfs. Letöltés ideje: 2020. december 28.

${ }^{15}$ Liu, E.: Investing Gets Cheaper as Fund Fees Continue to Fall. Barron's, 9 June 2020. https://www.barrons. com/articles/mutual-fund-fees-etf-passive-investing-financial-advice-morningstar-51591719173. Letöltés ideje: 2020. december 28.
} 


\subsection{Az ESG mint smart beta tényező}

A smart beta filozófia megjelenése és az ESG befektetési lehetőségek iránti emelkedő kereslet kombinálható, hogy új termékeket kínáljanak a befektetőknek. Az ESG a smart betában vonzónak tűnhet azok számára, akik diverzifikált részvény- (vagy kötvény)állományhoz kívánnak hozzáférést nyerni, de nem tetszik nekik a tény, hogy a nagy indexek olyan vállalatokat vagy iparágakat foglalnak magukban, amelyek károsítják a környezetet vagy rosszul bánnak az alkalmazottaikkal, vagy azok számára, akik magasabb hozamokat kívánnak elérni, mint a passzív ESG-alapok.

Már léteznek olyan alapok is, amelyek smart beta stratégiában ESG-kritériumokat alkalmaznak, és egyes kutatók ESG teljesítménytényezőket is kezdtek származtatni tágabb körű adatforrásokból (pl. Giese et al. 2016; Bender et al. 2017). Egy újabb felmérés szerint 2017 óta 40-ről 60 százalékra nőtt azon smart beta stratégiájú eszköztulajdonosok aránya, akik valamilyen ESG-szempont alkalmazásában gondolkodnak, ami az ESG növekedését jelzi ebben a terméktípusban is ${ }^{16}$.

Mivel az ESG-értékelések széles körben elérhetőek, a súlyokat rájuk lehet alapozni. Az alapkezelő dönt minden egyes értékelés súlyáról, és így több verziót lehet létrehozni, az enyhe módosítástól (ahol a különböző besorolási osztályok súlya egymáshoz közeli) a drasztikus átalakításig, ahol nagy a követési hiba. Az utóbbi opció kritika tárgyát képezheti, ha sok vállalatot teljesen kizárnak az indexből (azaz a súlyuk nulla), mivel ez nagyobb koncentrációs kockázathoz vezethet ${ }^{17}$. Másrészt az előbbi megközelítés esetleg csak gyenge próbálkozásnak tűnhet, azért hogy ESG-barátnak látsszunk. Mivel az ügyfelek preferenciája nem egységes, ajánlatos több ilyen alap-változatot létrehozni, hogy a befektetők a nekik jobban tetszőt választhassák. A smart beta befektetés jellege alapján több alap fenntartásának költsége nem lehet túl magas, és lehetővé tenné, hogy több befektető találjon megfelelő alapot, megnövekedett bevételeket eredményezve az alapkezelők számára.

Az ESG-értékeléseken mint tényezőn alapuló smart beta alap gondolata ESG-szempontból indokolhatónak látszik, de meglehet, hogy amennyiben a hozamok nem versenyképesek, soha nem terjed el. Az alábbiakban bemutatom, hogyan nézne ki egy ilyen alap, és milyen teljesítményre lehetne képes.

\footnotetext{
${ }^{16}$ Fedorova, A.: Investors are marrying ESG with smart beta. ESG Clarity, 20 August 2020. https://esgclarity. com/ftse-russell-research-august-2020/. Letöltés ideje: 2020. december 28.

${ }^{17}$ Pfeuti, E.: Smart Beta: Is this a match made in heaven? Funds Europe, December issue, Dec 2019 - Jan 2020. https://www.funds-europe.com/dec-2019-jan-2020/smart-beta-is-this-a-match-made-in-heaven. Letöltés ideje: 2020. december 28.
} 


\section{ESG-vel súlyozott smart beta EURO STOXX 50}

Példámban súlyokat rendeltem a EURO STOXX 50 indexben szereplő vállalatokhoz az MSCI ESG-értékeléseik alapján. Választásom azért esett erre az indexre, mert több fó európai piacot lefed, sok ágazatot tartalmaz, és minden egyes komponens rendelkezik MSCI ESG-értékeléssel. Az index közkézhányaddal korrigált piaci kapitalizációval súlyozott, ami igen fontos lesz számunkra.

\begin{tabular}{|c|c|c|c|c|c|c|c|c|c|c|}
\hline \multicolumn{11}{|c|}{$\begin{array}{l}\text { 3. táblázat } \\
\text { A EURO STO }\end{array}$} \\
\hline \multirow[b]{2}{*}{ Értékelés } & \multicolumn{2}{|r|}{2015} & \multicolumn{2}{|r|}{2016} & \multicolumn{2}{|r|}{2017} & \multicolumn{2}{|r|}{2018} & \multicolumn{2}{|r|}{2019} \\
\hline & Sz. & $\begin{array}{c}\text { A teljes piaci } \\
\text { kapitalizációból }\end{array}$ & Sz. & $\begin{array}{c}\text { A teljes piaci } \\
\text { kapitalizációból }\end{array}$ & Sz. & $\begin{array}{c}\text { A teljes piaci } \\
\text { kapitalizációból }\end{array}$ & Sz. & $\begin{array}{c}\text { A teljes piaci } \\
\text { kapitalizációból }\end{array}$ & Sz. & $\begin{array}{c}\text { A teljes piaci } \\
\text { kapitalizációból }\end{array}$ \\
\hline AAA & 15 & $22,7 \%$ & 18 & $31,7 \%$ & 18 & $32,0 \%$ & 17 & $31,2 \%$ & 17 & $32,1 \%$ \\
\hline AA & 12 & $24,9 \%$ & 12 & $22,7 \%$ & 9 & $18,0 \%$ & 8 & $17,1 \%$ & 8 & $13,6 \%$ \\
\hline A & 11 & $24,6 \%$ & 10 & $24,5 \%$ & 12 & $28,6 \%$ & 16 & $34,4 \%$ & 17 & $36,7 \%$ \\
\hline BBB & 10 & $22,8 \%$ & 8 & $17,1 \%$ & 9 & $17,6 \%$ & 6 & $11,0 \%$ & 5 & $12,0 \%$ \\
\hline BB & 0 & $0,0 \%$ & 0 & $0,0 \%$ & 1 & $1,5 \%$ & 2 & $3,6 \%$ & 2 & $3,2 \%$ \\
\hline B & 1 & $1,5 \%$ & 1 & $1,6 \%$ & 0 & $0,0 \%$ & 0 & $0,0 \%$ & 0 & $0,0 \%$ \\
\hline $\mathrm{CCC}$ & 1 & $3,5 \%$ & 1 & $2,5 \%$ & 1 & $2,3 \%$ & 1 & $2,7 \%$ & 1 & $2,5 \%$ \\
\hline
\end{tabular}

Mivel ez nagyon fontos indexnek számít, ezért az ötven komponense mindegyikének legalább öt év óta van MSCI ESG-értékelése. A 3. táblázat áttekintést nyújt arról, miként változtak az értékelések és a vonatkozó piaci kapitalizációk 2015 és 2019 között. Az egyetlen CCC minősítésű vállalat a Volkswagen, amely annak ellenére maradt az indexben, hogy jó hírneve jelentősen sérült a dízelbotrányban, és sok ESG-befektető bizalmát vesztette el. Összességében azt láthatjuk, hogy 2019-re az AAA minősítésű komponensek száma növekedett, miközben néhány, 2015-ben még $A A$ minősítésű vállalat 2019-re $A$ minősítésre esett vissza. Hasonló változás figyelhető meg a piaci kapitalizációs adatokból is, ahol az $A A A$ minősítések jelentősebbekké váltak az $A A$ minősítések rovására. Az $A$ minősítések száma és piaci kapitalizációja ugyancsak növekedett néhány $B B B$ vállalat minősítésének javulása miatt.

Két portfóliót hoztam létre: az egyik a mild (enyhe) ESG-portfólió, mert a súlyok nem nagyon különbözőek az értékelések között, míg a másik drasztikusabb, ezért drastic ESG-portfólióként fogom említeni. A portfóliók hozamai egy bizonyos időszakra vonatkozóan az alábbi súlyozási rendszerből kaphatók meg:

$$
r_{\text {portfolio }}=\sum_{i=1}^{n} \frac{x_{i}}{\sum x} \cdot \frac{P_{t}-P_{t-1}}{P_{t-1}}
$$


ahol $n$ az összetevők száma az indexben, $P_{t}$ a komponens záró ára az adott időszakban, $P_{t-1}$ a komponens záró ára az előző időszakban,

a mild ESG-portfólióra vonatkozóan:

$$
x_{i}=\left\{\begin{array}{cc}
3 & \text { ha a minősítés }=A A A \\
2,5 & \text { ha a minősítés }=A A \\
2 & \text { ha a minősítés }=A \\
1,5 & \text { ha a minősítés }=B B B \\
1 & \text { ha a minősítés }=B B \\
0,5 & \text { ha a minősítés }=B \\
0 & \text { ha a minősítés }=C C C
\end{array}\right.
$$

a drastic ESG-portfólióra vonatkozóan:

$$
x_{i}=\left\{\begin{array}{cc}
10 & \text { ha a minősítés }=A A A \\
5 & \text { ha a minősítés }=A A \\
2,5 & \text { ha a minősítés }=A \\
1,25 & \text { ha a minősítés }=B B B \\
0 & \text { ha a minősítés } \leq B B
\end{array}\right.
$$

A mild ESG-porfólió súlyozása a következő szabályon alapult: ha egy vállalatnak egy adott évben $A A A$ minősítése volt, 3 pontot kapott, és minden $A A A$ alatti minősítésért 0,5 pont levonásra került. A módszer mögötti érvelés az volt, hogy a leggyengébbtől eltekintve minden egyes osztályhoz pozitív értéket rendeljünk, miközben a besorolási osztályok közötti különbséget változatlanul tartjuk. Ezután a súlyok kiszámítása úgy történt, hogy a vállalat pontjait elosztottam az adott évi összes pont összegével. A drastic ESG-portfóliónak más pontrendszere volt: Az AAA 10 pontnak felelt meg, és a pontok minden $A A A$ alatti minősítés esetén megfeleződtek, miközben minden $B B B$-nél alacsonyabb minősítés nulla ponttal volt egyenlő, hogy nagyobb hangsúlyt kapjanak a magasabb minősítések, és kizárjuk a legrosszabb besorolási osztályokat.

A súlyok mindkét portfólióban évente változhatnak attól függően, hogy az adott évben a vállalat milyen minősítéssel bírt, és a többi vállalat milyen minősítést kapott. Megjegyzendő ugyanakkor, hogy az $\mathrm{MSCl}$ minden évben több adagban publikál vállalatokra vonatkozó ESG-értékelést, így a gyakorlatban negyedéves átsúlyozásra lehet szükség. Ezenkívül a mild ESG-portfólióban egy nem CCC minősítésű komponensre vonatkozóan előforduló nulla súly azért van, mert az adott minősítést abban az évben egyetlen vállalat sem érte el, míg a drastic ESG-portfólió esetén három minősítési kategória ki van zárva az eredeti indexportfólióból, ami összesen két vagy három vállalatot tesz ki minden egyes évben, miközben a mild ESG-portfólió ötvenből mindössze egy vállalatot zár ki. Ez azt mutatja, hogy még a szigorúbb portfólió se sérti jelentősen a diverzifikálás elvét. Ugyanakkor egyetlen vállalat se került kiszűrésre ágazati besorolás alapján, és így a portfóliók számos olaj- és gázcéget tartalmaznak, ami vitatható, de csak olyan mértékben vannak figyelembe véve, mint amennyire az ESG-értékelésük megengedi. 


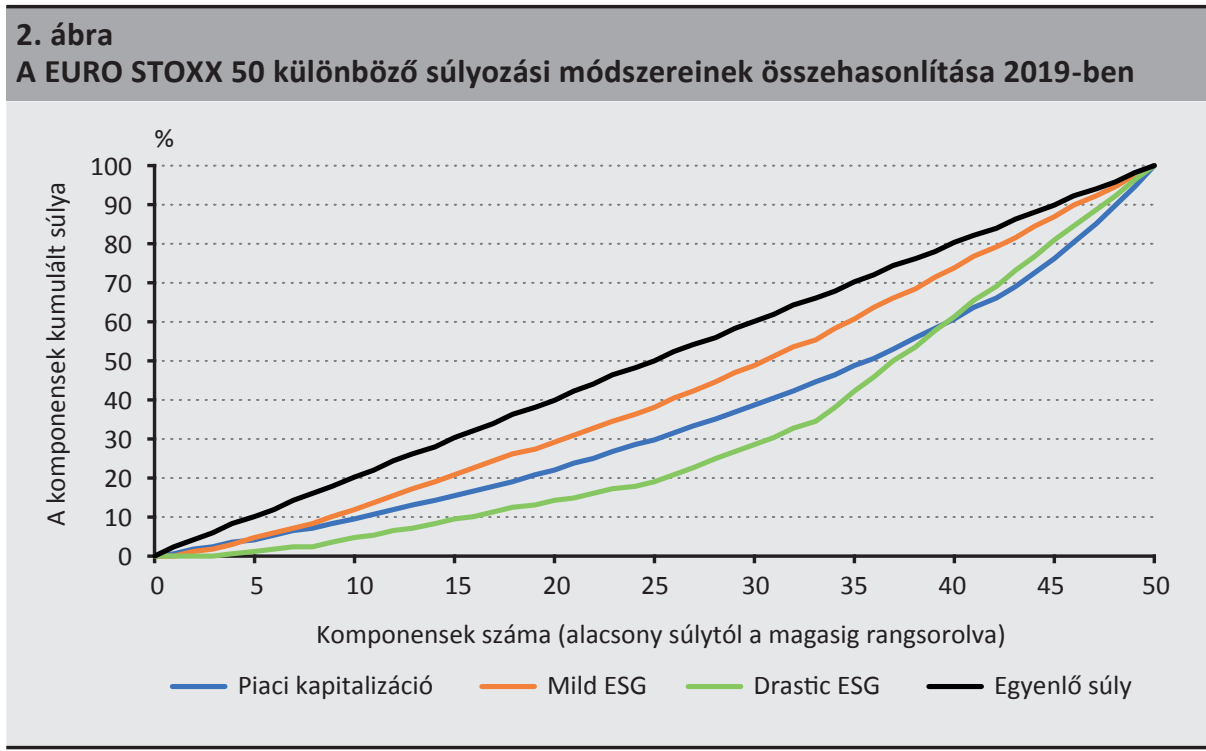

A 2. ábra azt mutatja, hogy a különböző súlyozási módszerek miként rendelnek súlyokat a EURO STOXX 50 indexösszetevőihez. A mild ESG-portfólió van a legközelebb egy egyenlően súlyozott portfólióhoz, miközben a drastic ESG-portfólió jobban alulsúlyozza azokat a komponenseket, amelyeknek gyenge az ESG-értékelése, mint amennyire a benchmark alulsúlyozza a kis piaci kapitalizációjúakat. Ugyanakkor a negyvenedik összetevőnél e két módszer metszi egymást, és a tíz legnagyobb hatású összetevőhöz a drastic ESG-portfólió kisebb súlyokat rendel, mint a benchmark. E jelenség azt mutatja, hogy a drastic ESG súlyozási módszer a benchmarknál kevésbé koncentrálódik pusztán néhány komponensre a portfólió teljesítményében. A benchmarkban a piaci kapitalizáció tekintetében öt legnagyobb vállalat kumulált súlya 2019-ben 24 százalék volt, míg a mild ESG-portfólióban az öt legjobb minősítésű vállalat teljes súlya mintegy 13 százalékot tett ki, és a drastic ESG-portfólióban ez az adat 19 százalék körül volt.

4. táblázat

A EURO STOXX 50 és a két ESG-portfólió éves hozamai 2015 és 2019 között

\begin{tabular}{l|c|c|c|c|c|c|c|c}
\multicolumn{1}{c|}{ Portfólió } & $\mathbf{2 0 1 5}$ & $\mathbf{2 0 1 6}$ & $\mathbf{2 0 1 7}$ & $\mathbf{2 0 1 8}$ & $\mathbf{2 0 1 9}$ & $\begin{array}{c}\text { Kumulatív } \\
\text { hozam }\end{array}$ & $\begin{array}{c}\text { Sharpe- } \\
\text { arány }\end{array}$ & $\begin{array}{c}\text { Sortino- } \\
\text { arány }\end{array}$ \\
\hline EURO STOXX 50 & $3,85 \%$ & $0,70 \%$ & $6,49 \%$ & $-14,34 \%$ & $24,78 \%$ & $19,03 \%$ & 0,30 & 0,66 \\
\hline Mild ESG & $11,79 \%$ & $6,58 \%$ & $11,52 \%$ & $-9,90 \%$ & $26,11 \%$ & $50,98 \%$ & 0,71 & 2,06 \\
\hline Drastic ESG & $12,68 \%$ & $8,37 \%$ & $12,38 \%$ & $-10,31 \%$ & $29,38 \%$ & $59,24 \%$ & 0,74 & 2,25 \\
\hline
\end{tabular}

A benchmark-portfólió és a két ESG-portfólió hozamait a 4. táblázat mutatja. Látható, hogy mindkét portfólió meglehetősen nagy különbséggel jobban teljesített, mint az eredeti, piaci kapitalizációval súlyozott. Az ötéves időszak során a mild ESG-port- 
fólió csak egyszer tudta megverni a drastic ESG-portfóliót, amikor a 2018-as visszaesés idején az AAA minősítésű vállalatok árfolyama az átlagot meghaladóan esett. A benchmarknál mindkét portfólió minden évben jobban teljesített.

Az egyes évek jobb hozamai jelentős különbséggé adódnak össze az ötéves időszakban: a drastic ESG-portfólió a benchmarknál háromszor jobb hozamot ért el, de még a mild ESG-portfólió is több, mint 31 százalékpontot vert a piacra. Az ESG-portfóliók kockázattal korrigált hozamai ugyancsak jelentősen magasabbak voltak a vizsgált időszakban. Ugyanakkor mivel a két portfólió pusztán hipotetikus, és tényleges befektetéshez nem áll rendelkezésre (vagyis semmilyen létező befektetési alap nem követi ezt a logikát), akik nem engedhették meg maguknak minden egyes összetevő megvásárlását, azok nem tudtak ilyen hozamokat elérni. Akárhogy is, a hozamok bizonyosan indokolnák ilyen alapok létrehozását a gyakorlatban is. Különböző piaci viszonyok, földrajzi helyek, iparágak vagy súlyozási módszerek mellett az eredmények eltérőek lehetnek, de a 2015 és 2019 közötti EURO STOXX 50 index esetén levonható az a következtetés, hogy ezen ESG súlyozási rendszer alkalmazásával a hozamok indokolnák ilyen alapok létrehozását, mivel többlethozamokat tudnának nyújtani a befektetők számára, miközben támogatják az ESG-vel kapcsolatos nemes célokat.

\section{5. táblázat}

Az egyes besorolási osztályok átlagos hozama 2015 és 2019 között

\begin{tabular}{l|c|c|c|c|c}
\multicolumn{1}{c|}{ Minősítés } & $\mathbf{2 0 1 5}$ & $\mathbf{2 0 1 6}$ & $\mathbf{2 0 1 7}$ & $\mathbf{2 0 1 8}$ & $\mathbf{2 0 1 9}$ \\
\hline AAA & $14,12 \%$ & $12,59 \%$ & $13,50 \%$ & $-12,14 \%$ & $34,53 \%$ \\
\hline AA & $11,26 \%$ & $-1,89 \%$ & $10,74 \%$ & $-3,78 \%$ & $20,10 \%$ \\
\hline A & $11,36 \%$ & $4,27 \%$ & $7,86 \%$ & $-10,70 \%$ & $19,13 \%$ \\
\hline BBB & $5,12 \%$ & $4,32 \%$ & $13,15 \%$ & $-1,77 \%$ & $18,32 \%$ \\
\hline BB & $0,00 \%$ & $0,00 \%$ & $-12,38 \%$ & $-37,85 \%$ & $19,32 \%$ \\
\hline B & $52,85 \%$ & $12,57 \%$ & $0,00 \%$ & $0,00 \%$ & $0,00 \%$ \\
\hline CCC & $-20,99 \%$ & $-3,90 \%$ & $23,36 \%$ & $-17,55 \%$ & $24,55 \%$ \\
\hline
\end{tabular}

Hogy jobban megértsük, mi hajtotta e hozamokat, érdemes megvizsgálni az egyes besorolási osztályok átlagos hozamát. Az 5. táblázatból látható, hogy az AAA minősítésű vállalatok az öt évből négyben jobban teljesítettek a többi osztálynál (kivéve azokat az osztályokat, amelynek csak egy komponense volt). Az AAA minősítésű összetevők jobb teljesítménye és indexbeli gyakoriságuk magyarázza, miért olyan nagy a benchmarktól való eltérés. Ugyanakkor nem világos, hogy valóban a magasabb ESG-értékelés volt-e azon összetevők magasabb hozamainak oka. Ezen elmélet ellenőrzése érdekében az ESG-értékeléseken túlmenően regressziós elemzéssel két másik tényezőt is megvizsgáltam:

$$
Y=\beta_{0}+\beta_{1} X+\epsilon
$$


Az első tényező a vállalatméret volt, a saját tőke könyv szerinti értékét használva helyettesítő értékként. A könyv szerinti értéket gyakran használják a befektetéseknél (különösen a piaci ár/könyv szerinti érték arányt), ugyanakkor más helyettesítők is elfogadhatóak lennének (továbbiakért lásd: Al-Khazali - Zoubi 2005). A másik vizsgált változó az egy részvényre jutó nyereség volt, miközben az ESG-értékelésekhez a drastic ESG-portfólió súlyozási rendszerét használtam, mivel az rámutat, hogy nehezebb egy magasabb ESG-értékelésen javítani, mint egy alacsonyabbon.

6. táblázat

Az ESG-értékelés, méret és nyereségnövekedés regressziós eredményei

\begin{tabular}{l|c|c|c} 
& ESG-értékelés & Méret & Nyereségnövekedés \\
\hline $\boldsymbol{\beta}_{\mathbf{0}}$ & $-0,01005$ & 0,11009 & 0,03116 \\
\hline $\boldsymbol{\beta}_{\mathbf{1}}$ & 0,00995 & $-0,00173$ & 0,22237 \\
\hline Standard hiba & 0,10834 & 0,09981 & 0,09980 \\
\hline $\mathbf{P}$-érték & 0,0277 & 0,000378 & 0,000376 \\
\hline $\mathbf{R}^{\mathbf{2}}$ & $9,70 \%$ & $23,35 \%$ & $23,37 \%$ \\
\hline
\end{tabular}

A vonatkozó regressziók eredményei alapján (6. táblázat) úgy találtam, hogy 0,0277 p-érték esetén az ESG-értékelés szignifikáns $\alpha=0,05$ szinten, akárcsak a másik két változó. Ugyanakkor az ESG-értékelések alacsony magyarázó erővel bírtak a mérethez és a nyereségnövekedéshez képest, arra utalva, hogy azok a tényezők jobban hozzájárultak a hipotetikus alapok jobb teljesítményének eléréséhez. A három tényezőt egy modellbe helyezve az ESG-értékelések p-értéke 0,05 fölé nőtt, de még szignifikáns változó volt $\alpha=0,1$ szinten.

$$
\begin{gathered}
Y=0,07+\begin{array}{c}
0,01 E S G \text { értékelés }-0,0016 \text { méret }+0,20 \text { nyereségnö } v .+\epsilon \\
(0,0895) \\
(0,00016)
\end{array} \quad(0,00014) \\
a d j . R^{2}=45,4 \%
\end{gathered}
$$

A másik két tényező továbbra is szignifikáns volt $\alpha=0,05$ mellett. A három kiválasztott tényező magyarázza a hozamok 45,4 százalékát. Ez az eredmény azt mutatja, hogy miközben az ESG-értékeléseket figyelembe kellene venni a befektetési döntésekben, más szempontokat is meg kellene fontolni.

Ezek a megállapítások összhangban vannak a portfóliók ESG-kritériumait vizsgáló más tanulmányokkal. Breedt et al. (2019) 2007 és 2017 közötti MSCl ESG-értékeléseket vizsgált, és úgy találta, hogy miközben az ESG-tényező nem csökkenti a hozamokat, a többlethozamhoz se járul hozzá a túlteljesítést magyarázó egyéb tényezők miatt (Small-minus-Big - kis és nagy méretű részvényekből álló portfóliók hozamai közötti különbség, momentum és alacsony béta). Ebben a tanulmányban az ESG-tényezőt szignifikánsnak találtam a EURO STOXX 50 esetében, de a túlteljesítés magyarázatához való hozzájárulása korlátozott, és másodlagos a mérethez és a nyereségnövekedéshez képest. Hasonló eredményt figyelt meg a Naffa - Fain (2020) 
szerzőpáros. Ők ESG-megatrendeket vizsgáltak, és arra a következtetésre jutottak, hogy a környezeti megatrendek (és egy vállalatirányítási megatrend) pozitiv alfákat hozhat, de a túlteljesítést a Fama-French 5-tényezős modell változói magyarázták.

\section{Alkalmazás a magyar piacra}

\subsection{ESG Magyarországon és az EU-ban}

Általában véve az Európai Unió a szabályozás és a befektetés tekintetében jelentős figyelmet fordít a fenntarthatóságra. Európa az ESG-befektetések kezdeményezője és vezetője volt, és továbbra is az ESG prominense maradt, miközben az egész világon megnövekedett érdeklődés mutatkozik a téma iránt. 2012-ben az ESG-befektetések Európában 8,8 billió USD-t tettek ki, amely összeg a világ ESG-befektetéseinek 66 százalékát teszi ki. 2018-ra ez az arány 46 százalékra esett, de az európai ESG-befektetések növekedése (14,1 billió USD-ra) továbbra is az összes többi régió elé helyezi a kontinenst ${ }^{18}$. Az ESG-befektetések iránti érdeklődés az előre láthatóan 2021-ben hatályba lépő új uniós rendelet miatt várhatóan tovább nő Európában. Ez arra késztetheti az alapokat, hogy elérhetővé tegyék portfólióik ESG-kategorizálását a befektetők számára. Ezzel nyomást gyakorolhatnak az alapkezelőkre és azok felső vezetésére, hogy felbecsüljék alapjaik hatását, és végrehajtsák a szükséges módosításokat a befektetéseik kiválasztásában, magasabb ESG-besorolás szerzése érdekében. $E$ kérdés meglehetősen fontos lehet, figyelembe véve, hogy az alapok intézményi ügyfelei (pl. nyugdíjalapok) nehezen magyaráznák meg az érdekeltjeiknek, miért döntöttek társadalmilag pusztító alapokba történő befektetés mellett. Mivel a lakossági befektetőkre a rendelet nem lesz közvetlen hatással, ők elméletileg bármibe befektethetnek, de a nagyközönség által az ESG iránt mutatott növekvő érdeklődés miatt és mert az alapkezelők szándékosan feltehetően nem hoznának létre rossz ESG-besorolású termékeket (mivel reputációs kockázatnak tehetnék ki munkaadójukat, még ha az ilyen termékek magasabb hozamokat ígérnének is), várhatóan e szegmens is ESG-intenzívebbé válik.

Ugyanakkor e tekintetben az EU-ban a helyzet heterogén. A skandináv országokat gyakran tekintik a világon vezetőnek az ESG területén, és a régiónak mind a vállalatai, mind az országai az ESG ranglisták tetején találhatók (3. ábra). E jelenség oka gyakran kötődik az északi emberek természethez füződő hagyományosan szoros kapcsolatához, de úgy túnik, az igazi ok a vállalati szintű erősebb „feminin” jellemzők (pl. a konzultálásra való összpontosítás a verseny és a magas státusz helyett), az egyenlőbb jövedelemeloszlás és a nagyobb átláthatóság kombinációja ${ }^{19}$.

\footnotetext{
${ }^{18}$ Ghosh, I.: Visualizing the Global Rise of Sustainable Investing. Visual Capitalist, 4 February 2020. https:// www.visualcapitalist.com/rise-of-sustainable-investing/. Letöltés ideje: 2020. december 28

${ }_{19}$ Potter, M.: Are Nordic businesses more sustainability conscious? Neste.com, 18 February 2020. https://www. neste.com/corporate-info/news-inspiration/articles/are-nordic-businesses-more-sustainability-conscious. Letöltés ideje: 2020. december 28.
} 
Amint azt a 3. ábra mutatja, Magyarország az ESG terén sereghajtó a kontinensen, és csak Bulgáriánál, valamint Romániánál teljesít jobban. Befektetési szempontból nehéz zöldrészvényt vásárolni az országban, elsősorban nem azért, mert Magyarországon a vállalatok kevésbé ESG-barát módon működnek, mint bárhol máshol, hanem azért, mert a legtöbbjüket nem jegyzik a tőzsdén, így értékpapírjaikat nem lehet megvásárolni. 2020-ban mindössze 37 magyar vállalatot jegyeznek a Budapesti Értéktőzsdén, közülük csak 20 van a prémium kategóriában. Jóllehet pénzügyi intézményekkel társulva az értéktőzsde próbálja hangsúlyozni a vállalatok a tőzsdére vitelének előnyeit, jelenleg a magyar piacon az ESG-lehetőségeket kereső befektetők azzal az akadállyal szembesülnek, hogy nincs megfelelő választék, ami jelentős koncentrációs kockázathoz vezethet. Ezt erősíti az is, hogy a legtöbb tőzsdén jegyzett magyar cég alacsony piaci kapitalizációja miatt az ESG-minősítő intézetek általában nem értékelik a teljesítményüket, emiatt nincs ESG-minősítésük. Például az MSCI csak a három legnagyobb tőzsdén jegyzett magyar vállalathoz (OTP, MOL, Richter) határozott meg minősítést 2020-ban, ami nehezíti a magyarországi ESG-befektetést. E jelenség más feltörekvő piacokon is megfigyelhető, ami a jövőben további munkát igényel az ESG-minősítő intézetektől, hogy az ESG-befektetés e piacokon is elterjedtebb legyen.

\section{3. ábra \\ Európai országok ESG Index (ESGI) pontszámai 2020-ban (az alacsonyabb értékek jobb eredményeket jelentenek)}

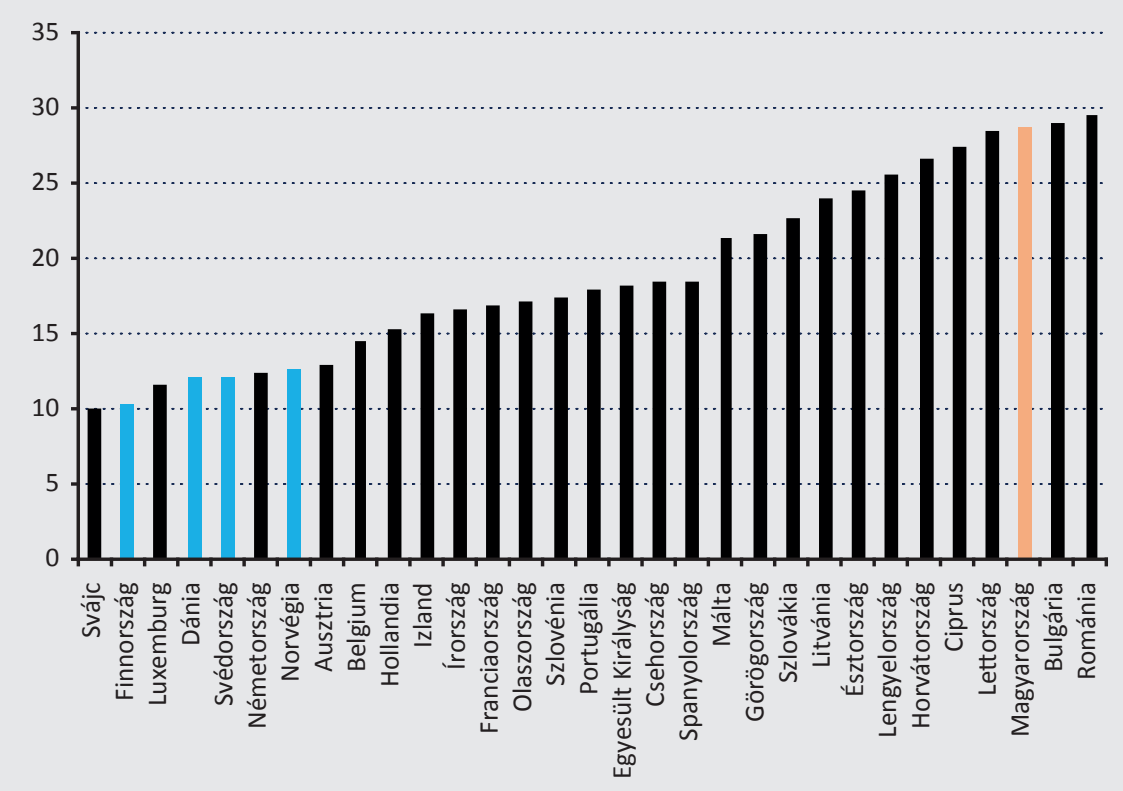

Forrás: https://risk-indexes.com/esg-index/. Letö/tve: 2020. december 28. 


\subsection{A smart beta ESG-befektetés alkalmazhatósága magyar alapokra}

A zöldrészvények választásának alternatívája, hogy olyan alapokba fektetünk, amelyek ezt a választást elvégzik helyettünk. Egyes magyarországi eszközkezelő cégek kínálnak valamilyen ESG-alapokat, de általában egy vagy két lehetőségnél nem többet. Zobor Zsuzsa, a K\&H Alapkezelő vezérigazgatója szerint nem sok magyarnak van tudomása az ESG-ről, és a vállalat eszközeinek csak kis hányadát helyezi ESG-befektetésekbe, ami jelentéktelen ahhoz képest, hogy belga anyavállalata új befektetéseinek 40 százaléka ESG-alapokkal kapcsolatos. ${ }^{20}$

Azt sugallja, hogy a Magyar Nemzeti Bank (MNB) nyújtson támogatást az ESG-alapok felügyeleti díjának csökkentésével (amely lényegében az alapokra kivetett adó). Ajánlása összhangban van az MNB már folyamatban levő tevékenységével, ami a pénzügyek zöldebbé tételére irányul Magyarországon konzultáció és oktatás kínálásával, hogy növelje a háztartások érdeklődését az elgondolás iránt. Az MNB-n kívül más intézmények is dolgoznak az ország ESG-teljesítményének javításán. 2020-ban sor került az első zöldkötvény-kibocsátásokra állami és vállalati szinten is. E kezdeményezések jelentős érdeklődést keltettek a piacon, ami arra utal, hogy érdemes lehet lépéseket tenni az ESG-ügyek irányába. A BAMOSZ (Befektetési Alapkezelők és Vagyonkezelők Magyarországi Szövetsége) ugyancsak felismerte az ESG-termékek iránti növekvő keresletet, és bejelentette, hogy 2021-től minden magyar alapot kategorizálnak ESG-kritériumok szerint. Azok az alapok, amelyek eltávolítják az ESG-szempontból „elfogadhatatlan” értékpapírokat, ESG-minősített besorolást kapnak, míg azok, amelyek az előbbi feltételen túlmennek, és felülsúlyozzák a pozitív ESG-teljesítményű eszközöket, az ESG-Plusz kategóriába léphetnek. A legfelső kategória, az ESG-Impact azon alapoké, amelyek impact investing stratégiát követnek ${ }^{21}$.

E kategorizálás megtörténte előtt a befektetők nehezen találnak ESG-alapokat. Egy, az MNB által kiadott konzultációs dokumentum szerint csak néhány alap neve tartalmaz valamilyen hivatkozást az ESG-re, amelyek a befektetésialap-piac teljes eszközértéke 0,4 százalékának felelnek meg (MNB 2019:11). Az a tény, hogy becslést csak egy igen gyenge mutató - az alapok neve! - alapján lehetett végezni, rámutat, hogy korábban nem volt olyan adatbázis, amely tartalmazta volna a magyarországi ESG-alapokat, vagyis a magyar befektetők a múltban többnyire nem érdeklődtek az ilyen befektetések iránt. Úgy tűnik, a fent említett dokumentum szerzői egyetértenek e megállapítással, mivel azt tanácsolják, hogy a magyar lakossági befektetők legalább öt évig tartsanak befektetéseket ESG-alapokban, ami viszont nem esik

\footnotetext{
${ }^{20}$ Xforest interjú Zobor Zsuzsával: https://xforest.hu/befektetes-es-klimavaltozas/. Letöltve: 2020. december 28.

${ }^{21}$ Fenntartható fejlödéssel kapcsolatos minősítési szempontokkal egészült ki a befektetési alapok kategorizálása. A BAMOSZ sajtóközleménye: https://www.bamosz.hu/en/web/guest/hirek?p_p_id=62_ INSTANCE_aU2V\&p_p_lifecycle=0\&p_p_state=maximized \&p_p_mode=view\&p_p_col_id=column-1 $\&$ p_p_ col_count $=1 \&$ 62_INSTANCE_aU2V_struts_action=\%2Fjournal_articles\%2Fview $\&$ _6 2 _INSTANCE_aU2V

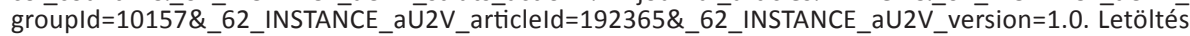
ideje: 2020. december 28.
} 
egybe szokásos viselkedésükkel, miután a kockázati étvágyuk többnyire alacsony (MNB 2019:12).

\begin{tabular}{|c|c|c|c|c|c|}
\hline \multicolumn{6}{|c|}{$\begin{array}{l}\text { 7. táblázat } \\
\text { A tíz legnagyobb magyar alapkezelő cég ESG-alapjai }\end{array}$} \\
\hline Eszközkezelő társaság & $\begin{array}{l}\text { Összes kezelt } \\
\text { eszköz 2019-ben } \\
\text { (millió HUF) }\end{array}$ & $\begin{array}{l}\text { Összes kezelt } \\
\text { ESG-eszköz } \\
\text { 2019-ben } \\
\text { (millió HUF) }\end{array}$ & $\begin{array}{c}\text { ESG-alapok } \\
\text { részesedése az } \\
\text { összes eszközből }\end{array}$ & $\begin{array}{l}\text { ESG-alapok } \\
\text { száma 2019-ben }\end{array}$ & $\begin{array}{l}\text { 2020-ban } \\
\text { létrehozott új } \\
\text { ESG-alapok }\end{array}$ \\
\hline OTP Alapkezelő & 1073448 & 8094 & $0,75 \%$ & 1 & 0 \\
\hline Erste Alapkezelő & 1036022 & 0 & 0 & 0 & 0 \\
\hline K\&H Alapkezelő & 891141 & 3197 & $0,36 \%$ & 2 & 1 \\
\hline $\begin{array}{l}\text { OTP Ingatlanbefektetési } \\
\text { Alapkezelő }\end{array}$ & 605292 & 0 & 0 & 0 & 0 \\
\hline $\begin{array}{l}\text { CIB Befektetési } \\
\text { Alapkezelő }\end{array}$ & 433341 & 0 & 0 & 0 & 2 \\
\hline Hold Alapkezelő & 415642 & 0 & 0 & 0 & 0 \\
\hline Budapest Alapkezelő & 317032 & 0 & 0 & 0 & 1 \\
\hline $\begin{array}{l}\text { MKB-Pannónia } \\
\text { Befektetési Alapkezelő }\end{array}$ & 307139 & 2624 & $0,85 \%$ & 1 & 0 \\
\hline $\begin{array}{l}\text { Aegon Magyarország } \\
\text { Befektetési Alapkezelő }\end{array}$ & 281265 & 0 & 0 & 0 & 1 \\
\hline Diófa Alapkezelő & 281107 & 0 & 0 & 0 & 1 \\
\hline Összesen & 5641429 & 13915 & $0,25 \%$ & 4 & 6 \\
\hline
\end{tabular}

2019-ben a tíz legnagyobb magyarországi eszközkezelő társaság által kínált ESG-alapok teljes részesedése mindössze 0,25 százalék volt, kevesebb, mint az MNB számítása szerinti (7. táblázat). A különbség abból a tényből fakad, hogy az MNB számítása 2019. január 31-re vonatkozott, míg én év végi adatokat használtam. Ezenkívül a 7. táblázatban csak a tíz legnagyobb eszközkezelő cég szerepel, miközben van még számos másik, kisebb piaci szereplő is. A táblázat azt mutatja, hogy a magyar eszközkezelő cégek csak négy ESG-alapot kínáltak; ezek mindegyikét aktívan kezelik. Ugyanakkor több alapkezelő cég kezdett kínálni ESG-alapokat, vagy bővítette meglévő ESG-termék-portfólióját 2020-ban. Az ESG-alapok száma mindössze egy év alatt négyről tízre nőtt, ami azt mutatja, hogy az alapkezelők látják az ESG-befektetések iránti kereslet növekedésének lehetőségét. Miközben az új alapok többségét továbbra is aktívan kezelik, 2020-ban létrehozták az első magyar passzív ESG-alapot is. Ugyancsak említésre érdemes, hogy néhány nagyobb európai alapkezelő cégnek van leányvállalata a tíz legnagyobb magyarországi között, és a magyar befektetők hozzáférhetnek az anyavállalatok ESG-alapjaihoz a leányvállalatok révén, ha ESG-ki- 
tettséget akarnak szerezni. Ugyanakkor mivel ezeket nem Magyarországon kezelik, általában euróban denomináltak.

2020-ban a magyar lakosság 66 százalékának volt valamennyi megtakarítása, ami 13 százalékpontos növekedést jelent 2017 és 24 százalékpontos növekedést 2015 óta. ${ }^{22}$ A legtöbb megtakarító ugyanakkor nem fektet semmibe, ehelyett inkább a bankszámláján (a megtakarítók 35 százaléka) vagy készpénzben ( 25 százalék) tartja a pénzét. E magatartás pénzügyileg nem tekinthető helyesnek, de ha úgy döntenének, hogy elkezdik befektetni megtakarításaik egy részét, a smart beta ESG-befektetés jó kiindulási pont lenne:

1. A korábban bemutatottak szerint a smart beta alapok költségrátái viszonylag alacsonyak (átlagosan 0,3 százalék), ami vonzó lehet az új befektetők számára, akik nem akarják hozamaik jelentős részét átadni az alapkezelőknek.

2. Az MNB konzultációs dokumentuma szerint az ESG-alapok egyik hátránya, hogy többleterőforrásokra van szükségük a megfelelő részvények kutatásának és kiválasztásának nehézsége miatt. Ugyanakkor egy smart beta módszerrel ez már nem gond, ha az alapok kezelői megbíznak az ESG-minősítő intézetben, és a tényező maga az ESG-értékelés, ami a stratégiát kevésbé erőforrás-intenzív törekvéssé teszi az alapkezelők számára (MNB 2019:12).

3. Amint azt korábban vizsgáltam, az utóbbi néhány év hozamai azt látszanak jelezni, hogy az ESG-befektetések legalább olyan jövedelmezőek, mint a szokásos befektetések, míg smart betával kombinálva megvan bennük a lehetőség, hogy túlteljesítsék a benchmarkot (amint az a EURO STOXX 50 esetében bemutatásra került), és jobban képesek átvészelni a külső sokkokat a hozzájuk kapcsolódó alacsonyabb kockázati szintek miatt.

Az alapkezelőknek mind a keresleti, mind a kínálati oldali előnyök megmutatkozására lehetőséget kell biztosítaniuk a befektetőknek, hogy megismerhessék ezeket az alternatívákat. Jelenleg egyetlen smart beta ESG-alap sem található a magyar piacon, de az ESG-alapok növekvő száma és az első passzív ESG-alap megjelenése ígéretes lépésnek tűnik a pénzügyitermék-fejlesztésben. A 3. ábrán bemutatott adatok szerint Magyarország a legtöbb európai országtól elmarad az ESG tekintetében, de az MNB, a BAMOSZ és maguk az alapkezelők törekvései azt jelzik, hogy ráébredtek az ESG növekvő fontosságára, és dolgoznak a jelenlegi helyzet javításán.

\footnotetext{
${ }^{22}$ A magyarok 66 százaléka rendelkezik megtakarítással, https://www.budapestbank.hu/sajtoszoba/1097-202002201453 és A magyar lakosság pénzügyi kultúrája, https://penziranytu.hu/magyar-lakossag-penzugyi-kulturaja alapján. Letöltés ideje: 2020. december 28.
} 


\section{Következtetések}

Az ESG-befektetés nyilvánvaló előnye, hogy a befektetők támogatni tudják a kívánatosabb vállalati tevékenységet célzó mozgalmat a társadalmilag pusztító vállalatok elkerülésével, de az is megmutatkozott, hogy az ESG-indexek az utóbbi években többnyire megfeleltek benchmarkjaiknak, vagy azoknál jobban teljesítettek. Úgy tűnik továbbá, hogy külső sokk idején (amilyen pl. a Covid-19-pandémia) a nagyobb társadalmi felelősségű befektetések csökkenteni tudják a veszteségeket.

Mivel a vállalatok ESG-teljesítményének meghatározása túl nagy kihívást jelentő feladat az egyének számára, ESG-minősítő intézetek jelentek meg. Szolgáltatásaik többnyire csak díj ellenében érhetők el, de azok a befektetők, akik nem kívánnak felárat fizetni, még mindig hozzáférhetnek az MSCI ESG értékelési módszerének végeredményeihez.

Az utóbbi évtizedben a passzív befektetés teret nyert az aktív befektetéssel szemben, de létezik alternatív megközelítés a két oldal közötti választásra: a smart beta stratégia. Mindkét megközelítésből van néhány jellemzője, de egyedisége egy olyan faktorból fakad, amely módosítja a benchmark-index eredeti súlyozását. Így a befektetők elkerülhetik, hogy egy indexbe fektetett tőkéjük nagyobb részét akaratlanul is a szélsőségesen nagy piaci kapitalizációval bíró néhány vállalatba helyezzék, miközben kevesebb kezelési díjat fizetnek, mint az aktív alapokért.

Mivel a smart beta módszerben a súlyozáshoz választott faktor sok formát ölthet, az ESG-értékeléseket fel lehet használni az ESG-nek a portfólióba foglalására. E megközelítéssel úgy találtam, hogy a EURO STOXX 50 index esetén a benchmarkot jelentősen túlteljesíthetik az ESG-értékeléssel súlyozott portfóliók. Ezen eredmény alapján javaslom olyan alapok létrehozását, amelyek a gyakorlatban is követik ezt a megközelítést, mivel a többlethozamok és az ESG-re való összpontosítás új ügyfeleket vonzhat az alapkezelők számára. Ugyanakkor miközben az ESG-értékelések szignifikánsnak találtattak, más tényezőknek (pl. méret és nyereségnövekedés) több hatása volt a hozamokra.

Megvizsgálva az ESG-befektetések magyarországi helyzetét, az a következtetésem, hogy jelenleg az országban a lakossági befektetők számára nincs túl sok ESG-befektetési lehetőség; mindazonáltal egyes alapkezelők és az MNB dolgoznak a fennálló állapot megváltoztatásán. A smart beta ESG-befektetés jó kiindulási pont lehet új befektetők számára, mivel jelentős pénzügyi nyereséget biztosíthat az aktívan kezelt alapokhoz képest alacsonyabb kezelési díjak mellett. Ilyen alapok létrehozása nem kíván határtalan erőforrásokat az alapkezelőktől, mivel rendelkezésre állnak az ESG-értékelések, és csak a módszertanukat kell áttekinteni. 


\section{Felhasznált irodalom}

Al-Khazali, O. - Zoubi, T. (2005): Empirical Testing Of Different Alternative Proxy Measures For Firm Size. Journal of Applied Business Research, 21(3): 79-90. https://doi.org/10.19030/ jabr.v21i3.1471

Anadu, K. - Kruttli, M. - McCabe, P. - Osambela, E. (2020): The Shift from Active to Passive Investing: Risks to Financial Stability? Financial Analysts Journal, 76(4): 23-39. https:// doi.org/10.1080/0015198X.2020.1779498

Arribas, I. - Espinós-Vañó, M.D. - García, F. - Tamošiūnienė, R. (2019): Negative screening and sustainable portfolio diversification. Entrepreneurship and Sustainability Issues, 6(4): 1566-1586. https://doi.org/10.9770/jesi.2019.6.4(2)

Bender, J. - Sun, X. - Wang, T. (2017): Thematic Indexing, Meet Smart Beta! Merging ESG into Factor Portfolios. The Journal of Index Investing, 8(3): 89-101. https://doi.org/10.3905/ jii.2017.8.3.089

Bernow, S. - Klempner, B. - Magnin, C. (2017): From 'why' to 'why not': Sustainable investing as the new normal. McKinsey \& Company. https://www.mckinsey.com/ /media/McKinsey/ Industries/Private\%20Equity\%20and\%20Principal\%20Investors/Our\%20Insights/From\%20 why\%20to\%20why\%20not\%20Sustainable\%20investing\%20as\%20the\%20new\%20normal/ From-why-to-why-not-Sustainable-investing-as-the-new-normal.ashx. Letöltés ideje: 2020. december 28.

Breedt, A. - Ciliberti, S. - Gualdi, S. - Seager, P. (2019): Is ESG an Equity Factor or Just an Investment Guide? The Journal of Investing ESG Special Issue, 28(2): 32-42. https://doi. org/10.3905/joi.2019.28.2.032

Cheah, E.-T. - Jamali, D. - Johnson J.E.V. - Sung, M.-C. (2011): Drivers of Corporate Social Responsibility Attitudes: The Demography of Socially Responsible Investors. British Journal of Management, 22(2): 305-323. https://doi.org/10.1111/j.1467-8551.2011.00744.x

Douglas, E. - Van Holt, T. - Whelan, T. (2017): Responsible Investing: Guide to ESG Data Providers and Relevant Trends. Journal of Environmental Investing, 8(1): 92-115. https:// cbey.yale.edu/sites/default/files/Responsible\%20Investing\%20-\%20Guide\%20to\%20 ESG\%20Data\%20Providers\%20and\%20Relevant\%20Trends.pdf. Letöltés ideje: 2020. december 28.

Escrig-Olmedo, E. - Munoz-Torres, M.J. - Fernandez-Izquierdo, M.A. (2010): Socially responsible investing: sustainability indices, ESG rating and information provider agencies. International Journal of Sustainable Economy, 2(4): 442-461. https://doi.org/10.1504/ IJSE.2010.035490 
Escrig-Olmedo, E. - Fernandez-Izquierdo, M. - Ferrero-Ferrero, I. - Rivera-Lirio, J. - MuñozTorres, M. (2019): Rating the Raters: Evaluating how ESG Rating Agencies Integrate Sustainability Principles. Sustainability, 11(3): 915-931. https://doi.org/10.3390/ su11030915

Giese, G. - Ossen, A. - Bacon, S. (2016): ESG as a Performance Factor for Smart Beta Indexes. The Journal of Index Investing, 7(3): 7-20. https://doi.org/10.3905/jii.2016.7.3.007

MNB (2019): Zöld pénzügyek Magyarországon. Konzultációs dokumentum, Magyar Nemzeti Bank. https://www.mnb.hu/letoltes/zold-penzugyek-konzultacios-dokumentum. pdf. Letöltés ideje: 2020. december 28.

Naffa, H. - Fain, M. (2020): Performance measurement of ESG-themed megatrend investments in global equity markets using pure factor portfolios methodology. PLoS ONE, 15(12): 1-34. https://doi.org/10.1371/journal.pone.0244225

Rompotis, G. (2009): Active vs. Passive Management: New Evidence from Exchange Traded Funds. https://doi.org/10.2139/ssrn.1337708

Talbot, D. - Boiral, O. (2018): GHG Reporting and Impression Management: An Assessment of Sustainability Reports from the Energy Sector. Journal of Business Ethics, 147: 367-383. https://doi.org/10.1007/s10551-015-2979-4

Townsend, B. (2020): From SRI to ESG: The Origins of Socially Responsible and Sustainable Investing. The Journal of Impact and ESG Investing, 1(1): 1-16. https://www.bailard.com/ wp-content/uploads/2020/09/History-Socially-Responsible-Investing-and-ESG-Investing. pdf?pdf=SRI-Investing-History-White-Paper. Letöltés ideje: 2020. december 28.

Trinks, P.J. - Scholtens, B. (2015): The Opportunity Cost of Negative Screening in Socially Responsible Investing. Journal of Business Ethics, 140: 193-208. https://doi.org/10.1007/ s10551-015-2684-3 